Na zakończenie należy zauważyć, że omawiana książka zawiera pewien akcent polski. Otóż w ostatecznej redakcji pomagał autorowi dyrektor młodego, ale już zasłużonego dla polskiej patrologii bydgoskiego wydawnictwa „Homini” - Krzysztof Bielawski. Wypada tylko życzyć, by konsekwencją tego udziału w publikacji rozprawy D. Hombergena, było jej rychłe nowe wydanie, tym razem w języku polskim.

ks. Mariusz Szram - Lublin, KUL

\title{
Ks. Mariusz SZRAM, Duchowy sens liczb w alegorycznej egzegezie aleksand- ryjskiej (II-V w.), Lublin 2001, Redakcja Wydawnictw KUL, ss. 470.
}

Zainteresowanie spuścizną Ojców Kościoła i pisarzy kościelnych pierwszych wieków już od ponad trzydziestu lat w naszym kraju znacznie się ożywiło. Przyczynilo się do tego kilku wybitnych uczonych, których uczniowie i kontynuatorzy zdążyli już sami pozyskać własnych uczniów i słuchaczy. Jednym $z$ takich uczniów, reprezentujących kolejne już pokolenie badaczy, jest ks. Mariusz Szram, którego praca pomyślana jako rozprawa habilitacyjna z powodzeniem wpisuje się na listę polskich osiągnięć w tej dziedzinie. Trzeba wszakże podkreślić, że problem alegorezy w odniesieniu do liczb we wczesnej tradycji patrystycznej nie znalazł do tej pory w polskiej bibliografii poważniejszego opracowania i tutaj praca ks. Szrama jawi się jako uzupełnienie dotkliwej luki w tym zakresie. Zdaje sobie $\mathrm{z}$ tego sprawę i Autor rozprawy, bo w obszernym wstępie, obejmującym niemal cały arkusz wydawniczy (ss. 7-28), a informującym dokładnie o stanie badań tej problematyki, sam pisze o zamiarze wypełnienia tej luki (s. 19).

W I rozdziale (ss. 29-95) zajął się Autor przedstawieniem nurtów symboliki liczb inspirujących wczesnochrześcijańską egzegezę aleksandryjską. Chcąc dać swemu studium podstawę historyczną, sięgnął najpierw do prac omawiających numerologię platońską i pitagorejską, by następnie przejść do egzegezy numerologicznej u Filona Aleksandryjskiego i kolejno - u pisarzy wczesnochrześcijańskich. Na końcu omawianego rozdziału znajdujemy omówienie symboliki liczb nawet w pismach gnostyckich. Ten szeroki przegląd przed- i wczesnochrześcijańskich oraz gnostyckich koncepcji, dotyczących interpretacji znaczenia liczb, posłużył Autorowi rozprawy za bazę dla kolejnego, II rozdziału (ss. 97-121), w którym przechodzi on już do omówienia założeń aleksandryjskiej egzegezy numerologicznej. Wlaśnie ta część pracy jest swoistym jej jądrem, bowiem przedstawione tutaj zostały znaczenia przypisywane liczbom biblijnym przez poszczególnych autorów aleksandryjskich. Ks. Szram zdaje sobie sprawę, że zakres symboliki liczb był u Aleksandryjczyków bardzo obszerny i obejmowal niekiedy nawet wykluczające się znaczenia. Myślę, że jest 
to też walorem pracy, iż jej Twórca nie stara się kamuflować pewnych niekoherencji dostrzeżonych w czasie lektury obranych przez siebie autorów, ale z solidnością właściwą prawdziwemu badaczowi ukazuje wnioski wynikające ze swoich dociekań.

W III i IV rozdziale (ss. 123-278) spotykamy rozważania dotyczące wielości sensu duchowego liczb i ich chrystocentrycznej hierarchizacji w egzegezie aleksandryjskiej. Omówione zostało więc kolejno znaczenie liczb: skrypturystyczne, kosmologiczne, antropologiczne, moralne, teistyczno-trynitarne, chrystologiczne, demonologiczne, eklezjologiczne, eschatologiczne i moralnomistyczne. Najistotniejszym jednak elementem aleksandryjskiej metody alegorycznej, zdaniem Autora, spotykanym we wszystkich formach pierwotnej egzegezy chrześcijańskiej, była typologia chrystocentryczna. Ks. Szram słusznie stwierdza, że sens chrystologiczny był $w$ tej egzegezie punktem węzłowym, do którego inne znaczenia przenośne miały konieczne odniesienie i bez którego nie miałyby racji bytu. W świetle tej symboliki liczb zbawczy charakter misji Syna Bożego stawał się jeszcze bardziej wyraźny. Alegoreza numerologiczna podkreślała $w$ tej misji nieskończone miłosierdzie Boze i wypływającą z ofiary Syna Bożego laskę odpuszczenia ludziom wszystkich grzechów. Ważną częścią pracy są rozważania dotyczące sensu eschatologicznego liczb i właśnie w odniesieniu do eschatologii alegoryczna interpretacja Aleksandryjczyków jest, w moim przekonaniu, najbardziej wiarygodna. Sam też Badacz stwierdzil, że docelowym sensem biblijnym w porządku chronologicznym byl dla Aleksandryjczyków sens eschatologiczny. I to właśnie interpretacja liczb w odniesieniu do tego sensu, dokonana przez autorów aleksandryjskich, daje najwięcej powodów do jej aprobaty. Rzecz oczywista, $\mathrm{z}$ enuncjacji studiowanych tekstów wyłaniały się również praktyczne wnioski, odnoszące się do moralności chrześcijan, i ma rację ks. Szram, gdy pisze, że symbolika liczb była środkiem nadającym się dobrze do określenia ilości i charakteru etapów, jakie miał do przejścia chrześcijanin na drodze postępu duchowego, oraz do ukazania grup, jakie tworzyli na tej drodze ludzie coraz bardziej doskonali.

W rozdziale V (ss. 279-372) ukazany jest historyczny rozwój aleksandryjskiej egzegezy numerologicznej, co stanowi jakby pewną prezentację jej ciągu rozwojowego. Czytelnik po przeczytaniu pracy ma świadomość, że Autor, mimo pewnych kwestii pobudzających do dyskusji, bynajmniej nie „odrobił zadania na temat", ale szczerze przejął się problemem, który sobie postawil, i pracę w całości przemyślał nie tylko od strony jej redakcji, ale także jej wewnętrznej zawartości, co właśnie jest najlepszą rękojmią solidności badawczej. Gdyby jednak brać pod uwagę tylko tę zewnętrzną stronę (a tego przecież żaden obiektywny i poważny czytelnik nie zrobi), to nawet tylko w tym wymiarze praca, ze względu na wartość porządkującą i klasyfikującą istotne problemy w niej zawarte, jest cenna i zasługuje na miejsce w wykazie 
bibliografii w tych dysertacjach, które o alegorezie w pismach pisarzy aleksandryjskich będą choćby tylko wspominać.

W trakcie jej lektury nasuwa się wiele myśli związanych $\mathrm{z}$ bardzo aktualnymi we wczesnym chrześcijaństwie koncepcjami eschatologicznymi, pobudzanymi przez Pismo św., a zwłaszcza Apokalipsę (ale nie tylko). Płodność tych doktryn była niemała, także i u późniejszych pisarzy dostrzegalna, choć niekoniecznie bezpośrednio wyrażana.

Książka ks. Mariusza Szrama, będąca rozprawą habilitacyjną, spełniła nie tylko wymagania stawiane jej jako rozprawie, ale zasługuje w pełni na to, by znaleźć się w rękach czytelników, którzy nie pracują naukowo na tym polu, lecz chcą pogłębić swą wiedzę z zakresu literatury wczesnochrześcijańskiej, a ich zainteresowania sięgają nieco głębiej; po jej przeczytaniu wiedza ta może okazać się przydatna także na terenie ich własnej działalności. Niewielki nakład pracy, jak zwykle uwarunkowany względami finansowymi, może zatem okazać się niewystarczający.

Jerzy Wojtczak-Szyszkowski - Warszawa

\section{BAZIL VELKÝ, Listy II. Hexaémeron, preložil, úvodnú štúdiu a vysvetlivky napísal a registre zostavil Daniel Škoviera, Bibliotheca Antiqua Christiana 2, Prešov 2002, Náboženské vydavatelstvo PETRA, ss. 295 + nlb. 1 + mapa 1.}

Oczekiwany przez czytelników kolejny tom słowackiej patrystycznej serii wydawniczej „Bibliotheca Antiqua Christiana” ukazal się w polowie 2002 roku. Podobnie jak pierwszy, tak i jej drugi tom ma dwuczęściową strukturę treściowo-wydawniczą. Pierwsza część tego drugiego tomu serii, zawierająca Listy z lat 375-378, oznaczone liczbą 193-334, jest kontynuacją epistolograficznego dorobku Bazylego Wielkiego. Druga część tomu, której zawartość stanowi dziewięć homilii Hexaémeronu, albo homilii o dziele stworzenia w sześciu dniach ${ }^{1}$, ukazuje fragment kaznodziejskiego dorobku tegoż wielkiego Ojca Kościoła z Cezarei Kapadockiej.

W nocie edytorskiej (s. 293) charakteryzującej całościowo strukturę wydanego tomu, thumacz wracając do historii przekładu Listów oraz ich konspiracyjnego wydania i upowszechnienia podczas totalitarnego prześladowania na Słowacji (1948-1989), przyznaje, że był świadom braków swojego dzieła. Wszystkie je usunął dopiero w związku z przyjęciem propozycji opublikowania Listów w serii „Bibliotheca Antiqua Christiana”. Wskazując na krytyczne wydanie greckiego tekstu $\mathrm{Y}$. Courtonne'a ${ }^{2}$ stanowiącego podstawę pracy tłu-

\footnotetext{
${ }^{1}$ Por. Sv. Bazil Velky, Hexaémeron ciže Homilie o diele Siestich dni, ss. 179-282.

${ }^{2}$ Por. Saint Basile, Lettres, éd. Yves Courtonne, II-III, Paris 1961 I 1966, Les Belles Lettres.
} 